\title{
Dental Management towards Sickle Patients: A Literature Review
}

QR CODE

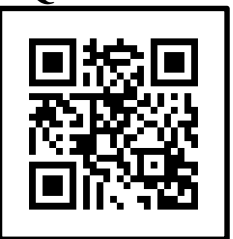

HEENA MAZHAR', RATNA SAMUDRAWAR², MUKESH KUMAR KASHYAP³, LUBNA TABASSUM SIDDIQUI ${ }^{4}$, POOJA S SALKAR 5

Sickle cell disease is an autosomal dominant haemoglobinopathy in which an abnormal form of hemoglobin (hemoglobin S) polymerizes under low oxygen saturation and alters normal spherical shaped RBCs into sickle shape. In India, sickle cell disease is prevalent in central and southern states like Chhattisgarh, Madhya Pradesh, Orissa, Maharashtra, Jharkhand, Karnataka, Kerala, and Tamil Nadu. In various districts like Korba, Kanker, Rajnandgaon, Durg, Bilaspur, Raipur, Dantewada, Bastar, Mahasumund, Dhamtari, Kawardha and Jangjir-Champa of Chhattisgarh, frequency of sickle cell disease are approximately $10 \%$. Screening results suggest that the prevalence of homozygous sickle cell disease was $2.1 \%$ and that of heterozygous sickle cell disease was $10 \%$ among different tribes. Prevalence rate among schedule tribe was $43.0 \%$, schedule caste was $18.26 \%$ and $35.3 \%$ among OBC group with the majority of cases reported in Agharia, Kurmi, Teli and Panika castes. Common oral findings of dental hypoplasia, delayed eruption, mucosal pallor, and radiographic changes are noticed in this disease. This paper aims to describe etiology, prevelance of sickle cell disease in chhattisgarh region and the role of dental surgeon for the management of such patients.

KEYWORDS: Sickle Cell Anemia, Sickling in Oral Surgery, Dentist.

\section{INTRODUCTION}

Sickle cell disease is an inherited hemoglobinopathy. 'James Herrick, was the first to describe sickle shaped red blood cells (RBCs) in 1910. Linus Pauling et al. reported altered electrophoretic mobility of sickle haemoglobin (HbS) in 1949. A few years later, Vernon Ingram in 1957 described its pathophysiology as, when 6th amino acid Glutamic acid of $\beta$ chain of Globin ( $\mathrm{HbA})$ is replaced by another amino acid Valine (HbS) at 11 chromosome of sickle haemoglobin. ${ }^{2}$ The life span of RBCs in such patients is only about 10 to 20 days and the bone marrow is not able to form new RBCs to replace rapidly destroying sickle $\mathrm{RBC}$ s resulting in hypochromic anemia. Crescent shaped RBCs have reduced elasticity causing them to become stiff, sticky which readily blocks blood flow in small capillaries. Blocking of blood flow results in ischemia which leads to severe pain and gradual damage to organs. Sickle cell disease has various forms like: homozygous sickle cell anemia (HbSS); sickle cell C disease(HbSC); sickle /beta thalassemia and other compound heterozygous conditions. Homozygous form of it is the most severe form clinically.

The genes for the beta globin chains are inherited as per mendalian's law when mutation inherited in a heterozygous manner, the individual receives only one gene codifying for $\mathrm{HbS}$. This defect is known as sickle cell trait (SCT). It is a carrier state and more common than homozygous sickle cell disease (HbSS). ${ }^{1}$ Prevalence of Sickle cell gene was first described by Lehmann and Cutbush in 1952 among South Indian tribal people. ${ }^{3}$ By Anthropological Survey of India (Negi 1972)4, sickle cell trait frequency of upto $35 \%$ reported mainly throughout of central India, like in Orissa, Chhattisgarh, Madhya Pradesh, Maharashtra and Gujrat (Balgir 1996: Ambedker et al. 2001) frequency of sickle cell disease in Orissa and Chhattisgarh were found to be approximately 10\% and $9 \%$ respectively.

At capital of Chhattisgarh state, Raipur a screening survey was conducted by Parta et al(2011). ${ }^{7}$ Results showed that the prevalence of sickle cell disease was $2.1 \%$ whereas sickle cell trait was $10 \%$ among different tribes with the majority of cases reported in Agharia, Kurmi, Teli and Sahu, Panika. ${ }^{8}$ (Table 1, Figure 1)

\section{PATHOPHYSIOLOGY}

It occurs due to single aminoacid substitution at 6th position of $ß$ chain amino acid where Glutamic acid of of Globin (HbA) is replaced by another amino acid Valine (HbS) at 11 chromosome. This leads to formation of $\mathrm{HbS}$ which undergoes polymerization when deoxygenated, the main 
event of sickle cell pathology. Rate of polymerisation depends on intra-erythrocytic $\mathrm{HbS}$ concentration, haemoglobin deoxygenation rate and its $\mathrm{pH}$. The resultant rope like polymer aligns to form a bundle causing distortion of red blood cells into characteristic sickle shaped RBCs. (Figure 2,3). These altered sickle red cells have reduced elasticity which sticks and occludes the circulation in small diameter capillaries causing infarction of organs leading to painful cramps. Haemolysis and vaso-occlusion are two main pathological changes noted in sickle cell disease. Haemolysis leads to hypochromic, hypovolemic anaemia with a functional deficiency of nitric oxide causing vascular endothelial damage which results in complications like pulmonary hypertension and stroke. Acute and chronic ischaemia due to vaso-occlusion is responsible for acute pain and organ damage. Signs and symptoms seen not only in homozygous sickle cell disease but also in compound heterozygous forms associated with $\mathrm{HbC}, \mathrm{HbS}$, ß-thalassemia, $\mathrm{HbE}$, and $\mathrm{HbO} .{ }^{9}$

\section{INHERITANCE PATTERN}

When both the parents have sickle cell trait, each child has a 50 percent chance of inheriting two sickle cell trait; a 25 percent chance of inheriting sickle cell disease; and a 25 percent chance of being normal without any disease (Figure 4).

\section{DENTAL MANIFESTATIONS}

As per Mendes et al. (2011) ${ }^{10}$, orofacial signs and symptoms noticed in sickle cell disease patients are as followings:-

1. Pallor of oral mucosa

2. Delayed tooth eruption

3. Dental hypoplasia

4. Atropy of tongue papillae

5. Intrinsic tooth opacity

6. Maxillary protusion

7. Recurrent mandibular pain

8. Mental nerve neuropathy

9. Mandibular osteomyelitis

10. Toothache

Occasionally, this disease may cause mandibular infarcts which may be mistaken as osteomyelitis.

Kaya et al. ${ }^{12}$ reported that sickle cell disease may cause pulp necrosis in those patients who had no past history of trauma or any dental restorations.
Sometimes, following sickle crisis, due to infarction of microvasculature of inferior alveolar nerve or its branches may cause permanent neuropathies. ${ }^{13}$ More recently, Scipio et al. ${ }^{14}$ reported acute facial swelling, gingival enlargement as a result of repeated haemorrhagic episodes and fibrous repair.

\section{DIAGNOSIS OF SICKLE CELL DISEASE}

Complete blood count ( $\mathrm{CBC}$ ) helps to identify the underlying bleeding disorders. Sickle shaped cells seen in blood smears, which varies from few to $40 \%$ of all red cells.

\section{MANAGEMENT OF SICKLE CELL CRISIS}

For moderate to severe pain, analgesic agent like morphine SC/IV should be started as soon as possible and may be continued as infusion till required. Moderate pain may be controlled by regularly administered oral codeine or oral morphine. Nonsteroidal anti-inflammatory analgesia and paracetamol should always be given unless there is renal or hepatic impairment, and may be sufficient for mild crisis.

- Fluid replacement by intravenous fluids at a rate of $80-100 \mathrm{ml} / \mathrm{kg} / 24$ hours should be used. ${ }^{15}$

- Oxygen therapy:- $100 \%$ oxygen should be given, if $\mathrm{O}_{2}$ saturation $<95 \%$.

Antibiotics: Intravenous antibiotics like cefotaxime $(50 \mathrm{mg} / \mathrm{kg}$ TID) or IV ceftriaxone $(50 \mathrm{mg} / \mathrm{kg}$ OD) should be started, if patient is febrile $>38$ Centigrade. Oral antibiotics could be started if condition improves. ${ }^{16}$

Blood Transfusion: Most of the patients with sickle cell disease are asymptomatic with haemoglobin of $6-7 \mathrm{gm} \%$, so, should not require transfusion. In symptomatic patients, where haemoglobin is less than $6 \mathrm{gm} \%$, transfusion is needed. Only in severe cases of sickle crisis like acute chest syndrome or cerebrovascular event, exchange transfusion should be considered under supervision of haematologist.

Exchange transfusion may be required preoperatively for certain surgical procedures (e.g., eye surgery and neurosurgery). Disease-modifying treatments should be used when there are frequent pain episodes or life-threatening events. Patients with severe complications, such as stroke 
and CNS complications, are usually transfused on a regular basis to reduce their $\mathrm{HbS}$ concentration (aim $<30 \%$ ) and to ensure a high haemoglobin level $(11-12 \mathrm{gm} \%)^{17}$

Hydroxyurea: This increases HbF levels, reduces lymphocytes and platelet count which in turn increases nitric oxide production, causing reduction in frequency and aggressiveness of sickle cell events.

Stem cell transplantation (SCT) is considered only when patients are not responding to other treatments, and if a HLA-compatible sibling donor is available. Matched unrelated SCT can also be performed; however, transplant-related mortality is higher than with sibling donor transplant.

Prophylaxis: In addition to routine vaccinations, patients with SCD require specific vaccination. All individuals with SCD have reduced splenic function and therefore reduced capacity to kill encapsulated bacteria. All patients should receive vaccination against Pneumococcus pneumoniae. Long-term daily use of oral penicillin is recommended. If liquid medication is used in children, then a sugar-free medication should be prescribed to minimize incidence of dental caries. As Sickle cell diseased patients undergo multiple blood transfusion during their life; therefore, hepatitis $\mathrm{B}$ vaccination is also recommended. Folic acid is also recommended for prolonged duration of use because of increased demand due to the high turnover of RBCs (haemolysis).

General anaesthesia: Koshy et al. $^{18}$ divided surgical procedures based on the risk in sickle diseased patients into three groups as follows: Low-risk procedures such as dental surgery, eyes, skin, extremities, perineal and inguinal surgery; Moderate risk procedures like genito-urinary system, intra-abdominal areas, tonsillectomy, caesarean section, splenectomy, cholecystectomy, hip replacement; High-risk procedures like intracranial, cardiovascular and intrathoracic surgery.

\section{DENTAL MANAGEMENT OF SICKLE CELL DISEASE PATIENT}

Prevention of dental disease to prevent occurrence of acute infection, which might trigger sickle cell crisis. In very young children, general anaesthesia should be avoided for elective dental treatment. A prophylactic preventive regime should be instituted in all such patients. Routine dental visits are recommended during eruption age of deciduous teeth. Advice and information should be given to prevent caries. Thereafter, patients should attend their dentist at least twice yearly, for fluoride varnish application, preventive advice and ongoing dental care throughout adulthood. Patients who have compromised splenic function should have antibiotics prescribed at the time of oral surgical procedures due to associated increased risk of local or systemic infections. If dental infection occurs, it must be promptly and adequately treated, as acute infections may trigger sickle crisis.

Conscious sedation may be used to manage anxiety during treatment under local anaesthesia. Dental treatment under conscious sedation or general anaesthesia should be done in a hospital setup where haematology expertise is available. ${ }^{19}$

\section{DISCUSSION}

Sickle cell disease carries ASA III anesthetic risk. Thus, Local anesthesia is generally preferred over general anesthesia for treating such patients as it does not lower the oxygenation of blood.

Among various types of local anesthetic agents, Lidocaine $2 \%$ with a vasoconstrictor like adrenaline $1: 80,000$ is preferred for routine extraction procedures. ${ }^{20}$ Prophylactic invasive surgeries like extraction of deeply impacted third molars, orthognathic surgeries should be avoided. Conscious sedation (nitrous oxide-oxygen) proved useful in pediatric patients with $>50 \%$ oxygen of high flow rate and adequate ventilation. In case, if general anesthesia is required, before its induction, proper hemoglobin levels should be obtained through transfusions, 10 to 15 days before the operation. Symptomatic patients with $\mathrm{Hb}$ $<6 \mathrm{gm} \%$ require blood transfusion. Optimum hemoglobin levels obtained after blood transfusions should lie in the range of $10-12 \mathrm{gm} \%$ for children and 8-10 gm\% for adults. Inhalation sedation is safe, as a minimum of $50 \%$ oxygen is used (much higher than room air oxygen). At the termination of nitrous oxide administration, $100 \%$ oxygen should be administered for approximately five minutes, to prevent rapid exhalation of nitrous oxide and the potential development of diffusion hypoxia. Prevent postoperative 
dehydration by giving IV normal saline (80$100 \mathrm{ml} / \mathrm{kg} / 24 \mathrm{hrs}$ ) and Ringer's Lactate solution is not preferable as lactate causes lactic acidosis.

Prophylactic Guidelines: A long term daily regimen of folic acid ( $5 \mathrm{mg} /$ day) should be given. Always schedule short term, morning dental appointments.For mild to moderate pain, use acetaminophen because salicylates may induce acidosis. Avoid elective surgery, like removal of asymptomatic impacted teeth. Incorporate home fluoride, fissure sealant therapy into the preventive dental treatment regimen. ${ }^{17,21}$

\section{CONCLUSION}

Patients having history of sickle haemoglobinopathy or from geographical areas where Sickle Cell Disease is prevalent, should be screened for it. A screening sickle solubility test (such as sickle-dex) should be arranged. If the results of this screening test are positive, then specific tests under the guidance of haematologist will be required to determine if SCT or SCD is present. No specific guidelines are required for dental treatment of sickle cell trait patients. However, if dental treatment under general anaesthesia is required for homozygous sickle cell patient, it should always be done in a hospital setup with expert haematologist.

\section{REFERENCES}

1. Serjeant GR, Serjeant BE, editors. Sickle cell disease, 3rd ed. Oxford: Oxford Univ Press; 2001.

2. Ingram VM. Gene mutations in human haemoglobin: the chemical difference between normal and sickle cell haemoglobin. Nature 1957; 180:326-8.

3. Lehman H, Cutbush M. Sickle cell trait in southern India. Brit Med J 1952; 1: 404-5.

4. Negi RS. Sickle cell trait in India. A review of known distribution. Bull Anthropol Survey India 1972;17:439-49.

5. Ambedkar SS, Phadke MA, Mokashi GD, Bankar MP, Khedkar VA, Venkat V, Basutkar DG. Pattern of haemoglobinopathies inwestern Maharastra. Indian Pediatr 2001;38:530-4.

6. Balgir RS. Genetic epidemiology of the three predominant abnormal haemoglobins in India. J Assoc Physicians India 1996;44:25-8.

7. Chauhan VS, Khodiar PK, Dalla AR, Serjeant GR. Screening for the sickle cell gene in Chhattisgarh state, India: an approach to a major public health problem. J Community Genet. 2011;2:147-51.

8. Panigrahi S, Patra PK. The screening and morbidity pattern of sickle cell anemia in Chhattisgarh. Indian J Hematol Blood Transfus 2015;31(1):104-9.

9. Neville BW, Damm DD, Allen CM, Bouquot JE. Oral and Maxillofacial Pathology. 2nd ed. Philadelphia: Saunders; 2002.

10. Mendes PH, Fonseca NG, Martelli DR, Bonan PR, de Almeida LK, de Melo LA. Orofacial manifestations in patients with sickle cell anemia. Quintessence Int 2011;42:701-9.

11. Cox GM. A study of oral pain experience in sickle cell patients. Oral Surg Oral Med Oral Pathol 1984;58(1):39-41.

12. Kaya AD, Aktener BO, Unsal C. Pulpal necrosis with sickle cell anaemia. Int Endod J 2004; 37(9): 602-6.

13. Friedlander AH, Genser L, Swerdloff M. Mental nerve neuropathy: a complication of sickle cell crisis. Oral Surg Oral Med Oral Pathol 1980; 49(1): 15-7.

14. Scipio JE, Al-Bayaty HF, Murti, PR, Matthews $\mathrm{R}$. Facial swelling and gingival enlargement in a patient with sickle cell disease. Oral Dis 2001; 7 (5): 306-9.

15. Okpala I, Thomas V, Westerdale N, Jegede, T, Raj K, Daley $\mathrm{S}$ et al. The comprehensive care of sickle cell disease. Eur J Haematol 2002; 68 (3):15762.

16. Rubenstein E. Studies on the relationship of temperature to sickle cell anaemia. Am J Med 1961; 30: 95-8.

17. Lewis, SM, Bain, BJ, Bates I. Practical Haematology, Churchill Livingstone, 2006: chapter 12.

18. Koshy M, Weiner SJ, Miller ST, Sleeper LA, Vichinsky E, Brown, AK, et al. Surgery and anaesthesia in sickle cell disease. Co-operative Study of Sickle Cell Diseases. Blood 1995; 86 (10): 3676-84.

19. Firth PG, Head CA. Sickle cell disease and anaesthesia. Anaesthesiology 2004; 101 (3): 766-

85.

20. Duggal MS, Bedi R, Kinsey SE, Williams SA. The dental management of children with sickle cell disease and beta-thalassaemia: a review. Int J Paediatr Dent 1996; 6 (4): 227-34.

21. Burrington, JD, Smith MD. Elective and emergency surgery in children with sickle cell disease. Surg Clin North Am 1976; 56 (1): 55-71. 
Source of support: Nil, Conflict of interest: None declared

Cite this article as:

Mazhar H, Samudrawar R, Kashyap MK, Siddiqui LT, Salkar PS. Dental

Management Towards Sickle Patients: A Literature Review. Int Healthcare Res J 2017;1(8):233-239.

\section{AUTHOR AFFILIATIONS:}

1. Consultant Oral and Maxillofacial Surgeon, Raipur, Chattisgarh

2. Consultant (Oral Medicine and Radiology), Raipur, Chattisgarh

3. Resident, Department of Oral and Maxillofacial Surgery, Rungta College of Dental Sciences and Research, Bhillai, Chattisgarh

4. Resident, Department of Priodontology, Chattisgarh Dental College and Research Institute, Rajnandgaon, Chattisgarh

5. Resident, Department of Oral and Maxillofacial Radiology, Chattisgarh Dental College and Research Institute, Rajnandgaon, Chattisgarh

\section{Corresponding Author:}

Dr. Heena Mazhar

Consultant Oral and Maxillofacial Surgeon

Raipur, Chattisgarh

+91- 9522915241

drheena101@gmail.com

\section{LEGENDS}

\begin{tabular}{|l|c|c|}
\hline \multicolumn{1}{|c|}{ Caste } & $\begin{array}{c}\text { \% of total population } \\
\text { of Chattisgarh }\end{array}$ & Incidence of Carrier in these cast groups \\
\hline Sahu & $12 \%$ & $25.7 \%$ \\
\hline Karmi & $10 \%$ & $\begin{array}{l}20 \% \text { including Mahavar, Verma, Parganiha, } \\
\text { Sinha, Chandravansi, Nayak, Bais, Baghel } \\
\text { and other }\end{array}$ \\
\hline Schedule Tribe & $18 \%$ & $20 \%$ \\
\hline Schedule Caste & $18 \%$ & $17 \%$ \\
\hline Total & $\mathbf{5 8 \%}$ & $\mathbf{8 2 . 7 \%}$ \\
\hline
\end{tabular}

Table 1. Percentages of various castes admitted with sickle cell disease in hospital 


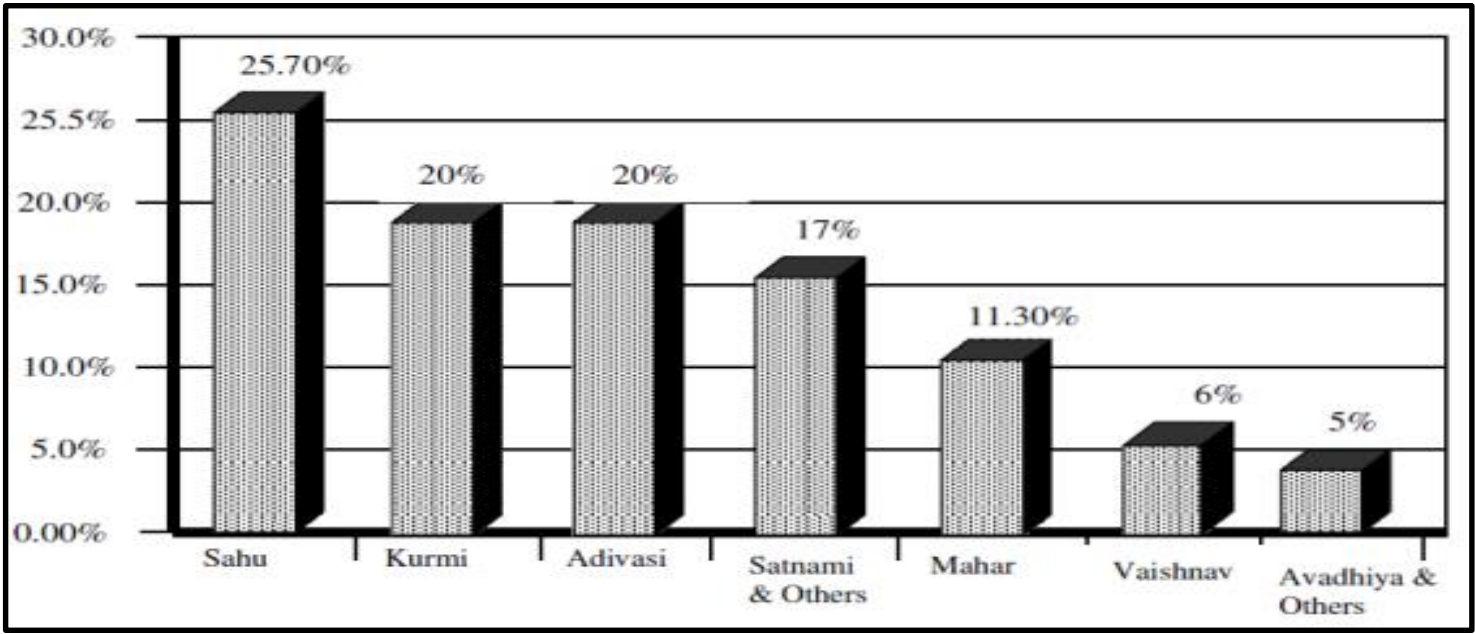

Figure 1. Distribution of carriers of sickle cell gene in various castes of Chattisgarh

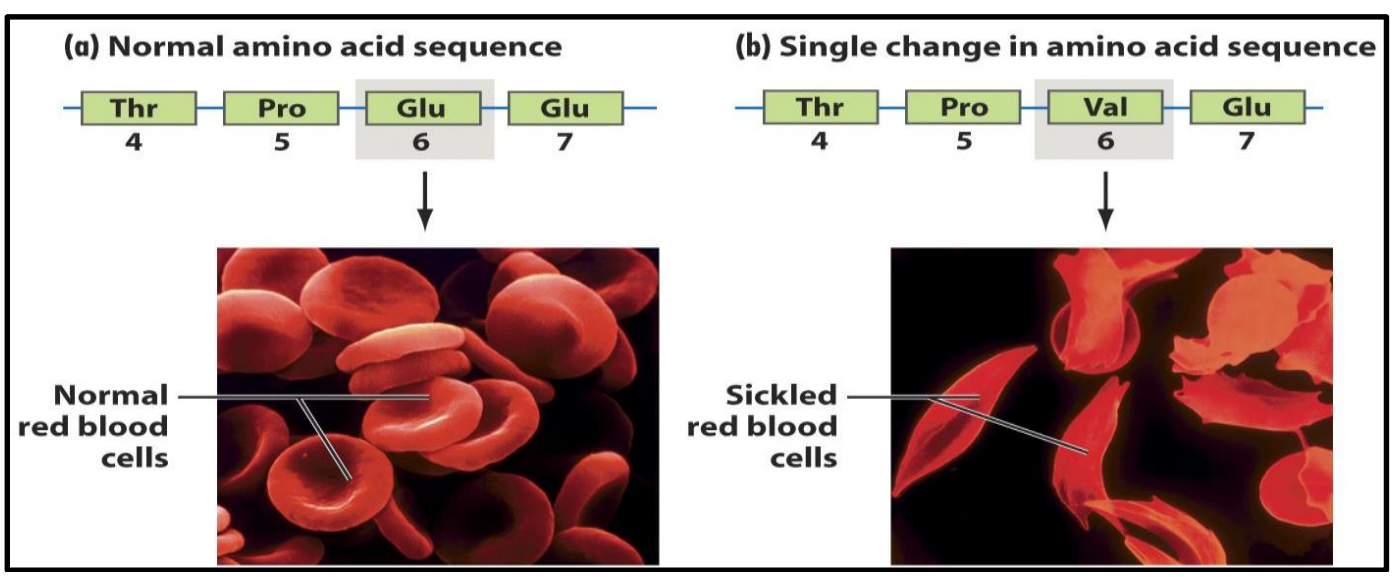

Figure 2. Pathophysiology of sickle cell disease 


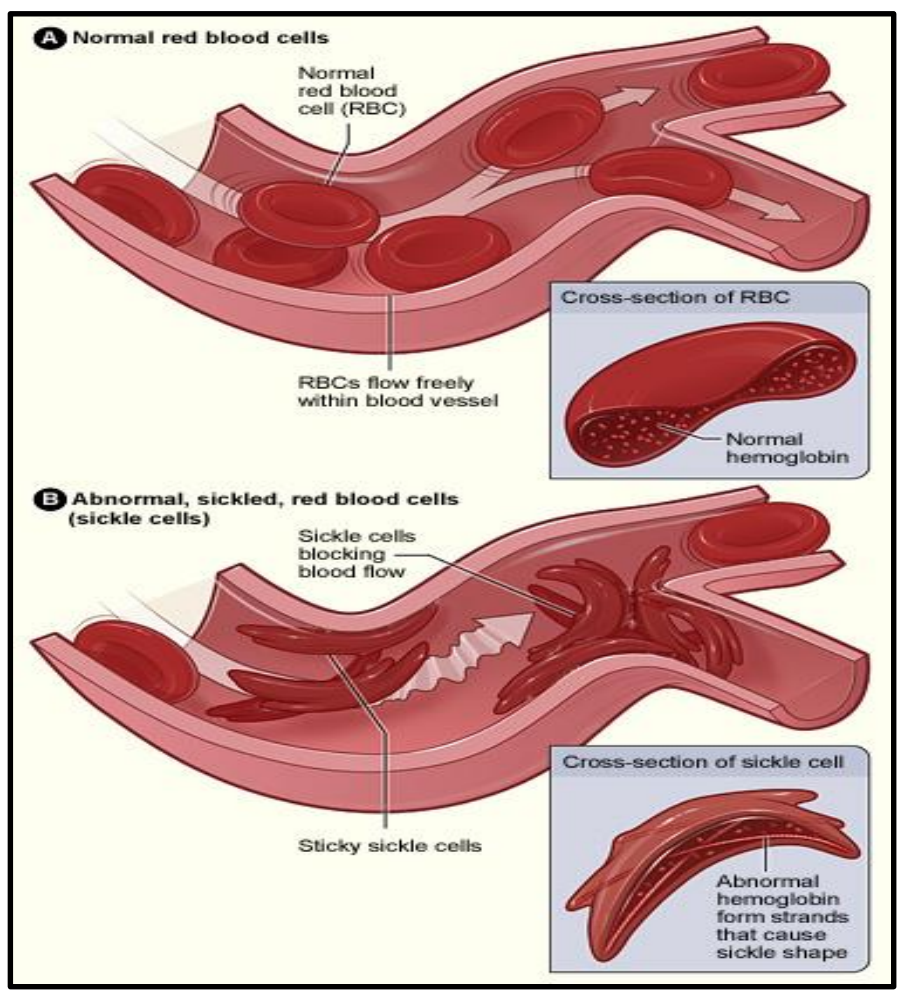

Figure 3. Pathophysiology of sickle cell disease

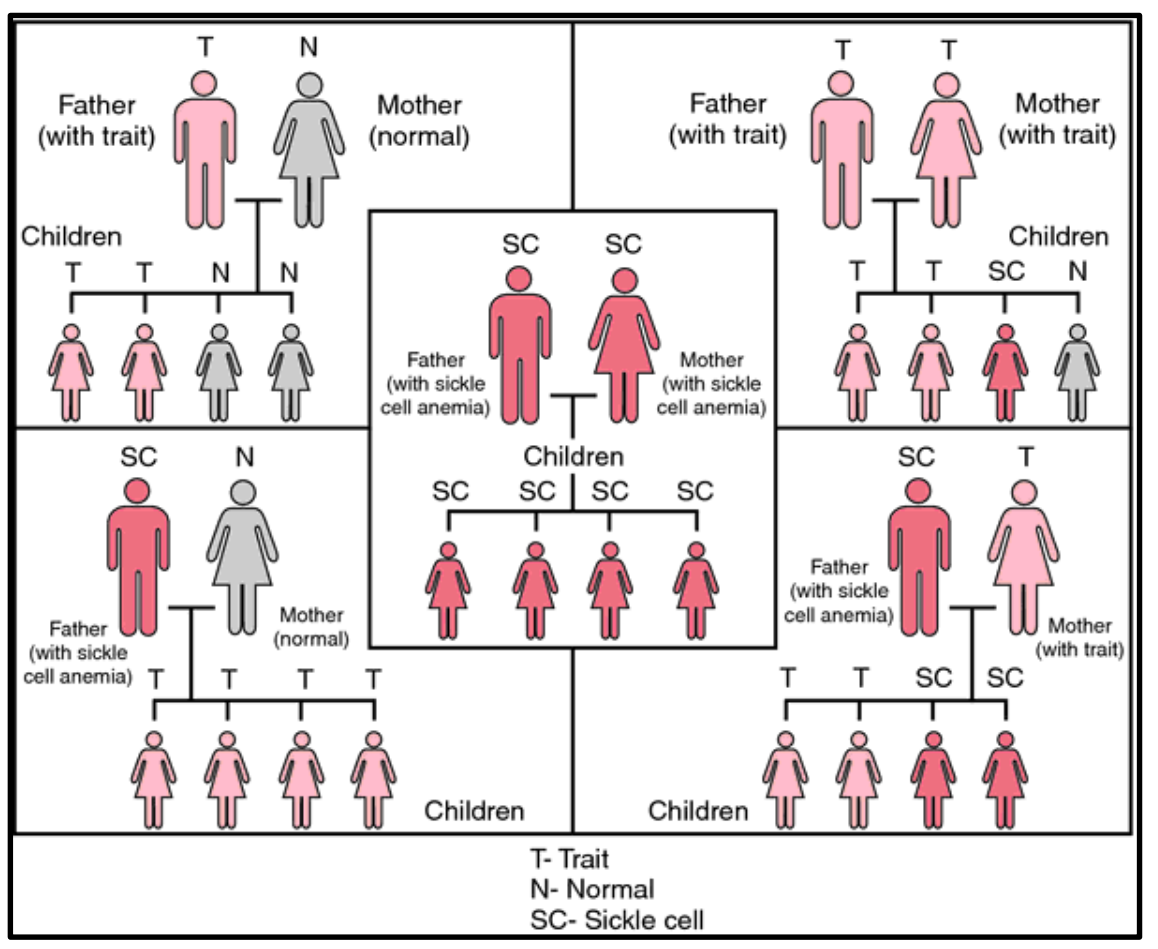

Figure 4. Inheritance pattern of sickle cell disease 